\title{
Significance of Fruit and Seed Coat Morphology in Taxonomy and Identification for Some Species of Brassicaceae
}

\author{
Dalia G. Gabr ${ }^{1,2}$ \\ ${ }^{1}$ Department of Basic Science, Faculty of Education, Imam Abdulrahman Bin Faisal University, Dammam, Saudi Arabia \\ ${ }^{2}$ Botany and Microbiology Department, Faculty of Science (Girls Branch), AL Azhar University, Cairo, Egypt \\ Email: dggabr@iau.edu.sa
}

How to cite this paper: Gabr, D.G. (2018) Significance of Fruit and Seed Coat Morphology in Taxonomy and Identification for Some Species of Brassicaceae. American Journal of Plant Sciences, 9, 380-402. https://doi.org/10.4236/ajps.2018.93030

Received: January 2, 2018

Accepted: February 10, 2018

Published: February 13, 2018

Copyright $\odot 2018$ by author and Scientific Research Publishing Inc. This work is licensed under the Creative Commons Attribution International License (CC BY 4.0).

http://creativecommons.org/licenses/by/4.0/

\section{(c) (i) Open Access}

\begin{abstract}
Fruit, seed morphology and seed coat sculpturing were recorded for 10 species belongs to 9 genera and five tribes of Brassicaceae in eastern region of Saudi Arabia by using light microscope (LM) and scanning electron microscope (SEM). Four seed patterns were recognized based on surface sculpturing pattern; Reticulate, with four subtypes, undulate, verrucate and ocellate. The results of numerical analysis showed that species were grouped into two major clusters and each cluster divided into two groups. The cluster analysis indicates that the characters of fruit and seed are very important characters for identification and taxonomical classification of the tribes. The results indicate that the most tribes of Brassicaceae are polyphyletic, and some are related to each other's as Lepidieae, Alyssieae and Sisymbrieae.
\end{abstract}

\section{Keywords}

Fruit, Seed Coat, Morphology, Scanning Electron Microscope

\section{Introduction}

The Brassicaceae (Cruciferae), or mustard family, is one of the largest angiosperm families, can be recognized easily by its floral and fruiting characters. It is cosmopolitan but chiefly distributed in the temperate and Mediterranean region, it represented by 338 genera and 3709 species [1]. In Saudi Arabia, it is represented by 53 genera and 74 species [2]. In eastern region of Saudi Arabia, [3] recorded 46 species and 30 genera.

The morphological characters of the family Brassicaceae especial fruit seed and cotyledons are used in the tribal classification of the family [4] recognized 
10 tribes based on fruit and cotyledon characters. [5] recognized 4 tribes and 19 sub tribe, then [6] put the members of the family in 10 tribes by using nectar glands and myrosin cells characters. [7] divided the family into three groups according to fruit characters into Siliquosae, Siliqulosae and Lomentaeae, each composed of number of tribes. [8] classifies the genera of the family in 19 tribes. [9] reduced the total number of Schulz's tribes from 19 to 15 tribes depending on very large numbers of features of flowers and fruit. [10] recognized 6 tribes under the family Cruciferae according to fruit characters, but [11] divided the family into 6 groups and 10 tribes. [12] [13] reduced Schulz's tribes to three tribes: The lypodieae, Brassiceae and Sisymbrieae. [14] classified the family Brassicaceae of the southeastern United States into 7 tribes; then [15] recognized 25 tribes for the family Brassicaceae. Recently there are some researches based on molecular and phylogenetic studies for the family as [16]-[29].

The morphology of seed coat structure is considered to be stable characters and is little influenced by external environmental conditions whilst the seeds develop and ripen within the fruit [30] [31] [32] [33]. The seed coat characters have been used successfully to solve systematic and phylogenetic problems between different taxa [34] [35]. In the Brassicaceae, several studies have been carried out on the seed coat and its taxonomic significance. [36] [37] [38] [39] studied the external morphology and anatomy of seeds of 90 genera and 200 species of the Cruciferae. [40] [41] [42] investigated the seed coats and development of epidermal slime bodies of Malcolmia. [43] studied the seed coat of Lepidium in East tropical Africa. [44] investigated the structure of seed coat and development in certain species of Brassicaceae. [45] [46] studied some taxa of Brassica seeds by using scanning electron microscope (SEM). [47] used SEM on the seed surface to distinguish Matthiola, Morettia, and Diceratella. [48] studied the seed coat morphology, particularly the epidermal slime structure of Morettia. [49] studied the seed coat of genus Farsetia by using SEM to distinguish between species. [50] investigated the seed coat sculpture in species of the tribe Brassiceae in Egypt by using SEM. [51] investigated the seed morphology and taxonomy with SEM in the tribe Lepidieae in Egypt. More recently, [52] gave detailed descriptions of seed morphology in 44 species of the subtribes Brassicinae, Raphaninae and Moricandiinae, and elucidated the phylogenetic relationships between taxa. [53] study seed morphology of 45 taxa belonging to 23 genera from tribes Arabideae, Euclidieae, Hesperideae, Lunarieae, Matthioleae, and Sisymbrieae, of Brassicaceae were examined using light and scanning electron microscopy. [54] studied the macro and micromorphological characters of approximately 22 genera, 30 species of Brassicaceae. [55] study seed coat sculpture of 93 taxa belonging to 45 genera of the family Brassicaceae from Egypt by using light and scanning electron microscope. [56] investigated seed morphology and seed coat sculpturing of 32 Taxa of Family Brassicaceae by using light microscope and scanning electron microscope. [57] study the relation between 26 taxa of family Brassicaceae from Egypt by using morphological characters including fruit and 
seed characters, [58] study the seed exomorphic characteristics of 14 taxa of Lepidium L. in Brassicaceae from Turkey by light microscope and scanning electron microscope (SEM). [59] study macro and micromorphological characters of 9 species and 30 accessions seeds in Ricotia L. by light (LM) and scanning electron microscopy (SEM) to evaluate the taxonomic relevance of these traits. [60] studies the morphological Characteristics of some species of Brassicaceae (Cruciferous) in Setifian High Plateau, Algeria.

The fruit and seed coat morphological feature in Brassicaceae species growing in eastern region of Saudi Arabia is not yet correctly projected. Therefore, our knowledge about the fruit and seed coat morphology of these plants is only measly. Therefore the main objective of this study is to examine and describe the fruit and seed coat of some species of Brassicaceae growing in eastern region of Saudi Arabia by using light and scanning electron microscope to indicate the important of these characters for taxonomy and identification of different species.

\section{Material and Methods}

Ten species belong to nine genera were collected fresh in spring season from different area in eastern region of Saudi Arabia (Table 1). The materials studied were identified according to plant key of [2] [3]. Foliar details for fruit and seed were examined with the aid of binocular stereo microscope (Olympus Bx53). The details of seed morphology were investigated in electron scanning microscope (SEM) with the use of FEI, ISPECT S50 (Czech Republic). SEM was operated at $20 \mathrm{kV}$ with working distance $10 \mathrm{~mm}$. Long and high magnification was performed to capture the recognized features of the specimen. The seeds were

Table 1. Collection data of the studied species and its tribal classification. All species from eastern region of Saudi Arabia.

\begin{tabular}{|c|c|c|c|c|}
\hline \multirow{2}{*}{ Species } & \multirow{2}{*}{ Locality and date } & \multicolumn{3}{|c|}{ Tribes } \\
\hline & & Prantl (1891) & Schulz (1936) & Al-Shehbaz, et al., (2006) \\
\hline Brassica juncea (L.) Czern & Rawda-Dammam, 3/2017 & Sinapeae & Brassiceae & Brassiceae \\
\hline Brassica tournefortii Gouan & $\begin{array}{l}\text { Rayan-Dammam, 3/2017 } \\
\text { Rawda-Dammam, 3/2017 }\end{array}$ & Sinapeae & Brassiceae & Brassiceae \\
\hline Eruca sativa Mill & Rawda-Dammam, 4/2017 & Sinapeae & Brassiceae & Brassiceae \\
\hline Raphanus sativus $\mathrm{L}$. & Rawda-Dammam, 4/2017 & Sinapeae & Brassiceae & Brassiceae \\
\hline Cakile arabica vel. et Bornm & $\begin{array}{l}\text { Rayan-Dammam, 3/2017 } \\
\text { Rawda-Dammam, 3/2017 }\end{array}$ & Sinapeae & Brassiceae & Brassiceae \\
\hline Savignya parviflora (del.) Webb & Rayan-Dammam, 3/2016 & Sinapeae & Brassiceae & Brassiceae \\
\hline Coronopus didymus (L.) Sm. & Rayan-Dammam, 3/2017 & Sinapeae & Lepidieae & Lepidiea \\
\hline Farsetia burtonae Oliv. & Salasal_Dammam road, 4/2017 & Hesperideae & Alysseae & Alysseae \\
\hline Cardamine hirsuta $\mathrm{L}$. & Rayan-Dammam, 3/2017 & Sinapeae & Arabideae & Cardamineae \\
\hline Sisymbrium irio L. & Rayan-Dammam, 3/2017 & Sinapeae & Sisymbrieae & Sisymbrieae \\
\hline
\end{tabular}


mounted onto a metallic stub with a double-sided adhesive tape. Gold coating of few nanometers was applied using sputter coating machine (Quorum, Q150R ES, UK) to avoid charging and capture high quality images.

The terminology of [32] [61] [62] was adopted to describe the SEM aspects of the seed coat. The morphological characters of the fruit and seed for the studied species were collected and creating data matrix used for numerical analysis. The relationships between the studied species have been demonstrated as dendrograms Figure 4 by using PRIMER 6, version 6.1.6 analyses using agglomeration of Schedule measure Euclidean distance, using complete linkage between groups.

\section{Results}

The fruit and seed morphological characters for ten species of the family Brassicaceae are summarized in Tables 2-6 and the image by and SEM are represented in Figures 1-3.

\subsection{Fruit Characters}

\subsubsection{Fruit Pedicel}

The texture of pedicel is glabrous in most studied species except in Coronopus didymus and Farsetia burtonae are hairy. The pedicel length has greeted variation in the studied species; it ranged from short, long and very long pedicel. Short (2-5 mm) recorded in Eruca sativa, Cakile arabica, Coronopus didymus, Farsetia burtonae, and Cardamine hirsute. Long (6 - $10 \mathrm{~mm})$ present in Brassica juncea, Brassica tournefortii and Sisymbrium irio. Very long (more than $10 \mathrm{~mm}$ ) present in Raphanus sativus and Savignya parviflora.

\subsubsection{Fruit Types}

The family Brassicaceae is characterized by two types of fruit; siliqua and silicula, in the present study the silicula fruit noted in Savignya parviflora and Coronopus didymus. The reminder studied species have the type of siliqua.

\subsubsection{Fruit Segmentation}

Most studied species are non-segmented, segmented fruit are present in Raphanus sativus, Cakile Arabica and Farsetia burtonae.

\subsubsection{Fruit Shape}

The shape of fruit showed great variation. In the studied species the fruit shape recorded three main types; linear or terete in Brassica juncea, Brassica tournefortii, Farsetia burtonae, Cardamine hirsute and Sisymbrium irio. Oblong in Eruca sativa, Raphanus sativus, Cakile arabica and Savignya parviflora. Subreniform in Coronopus didymus.

\subsubsection{Fruit Surface $\&$ Texture}

The texture in half studied species is glabrous with non-ribbed surface. Glabrous and ribbed in Raphanus sativus, Cakile arabica and Sisymbrium irio. Tuberculated and not-ribbed in Coronopus didymus and hairy in Farsetia burtonae. 


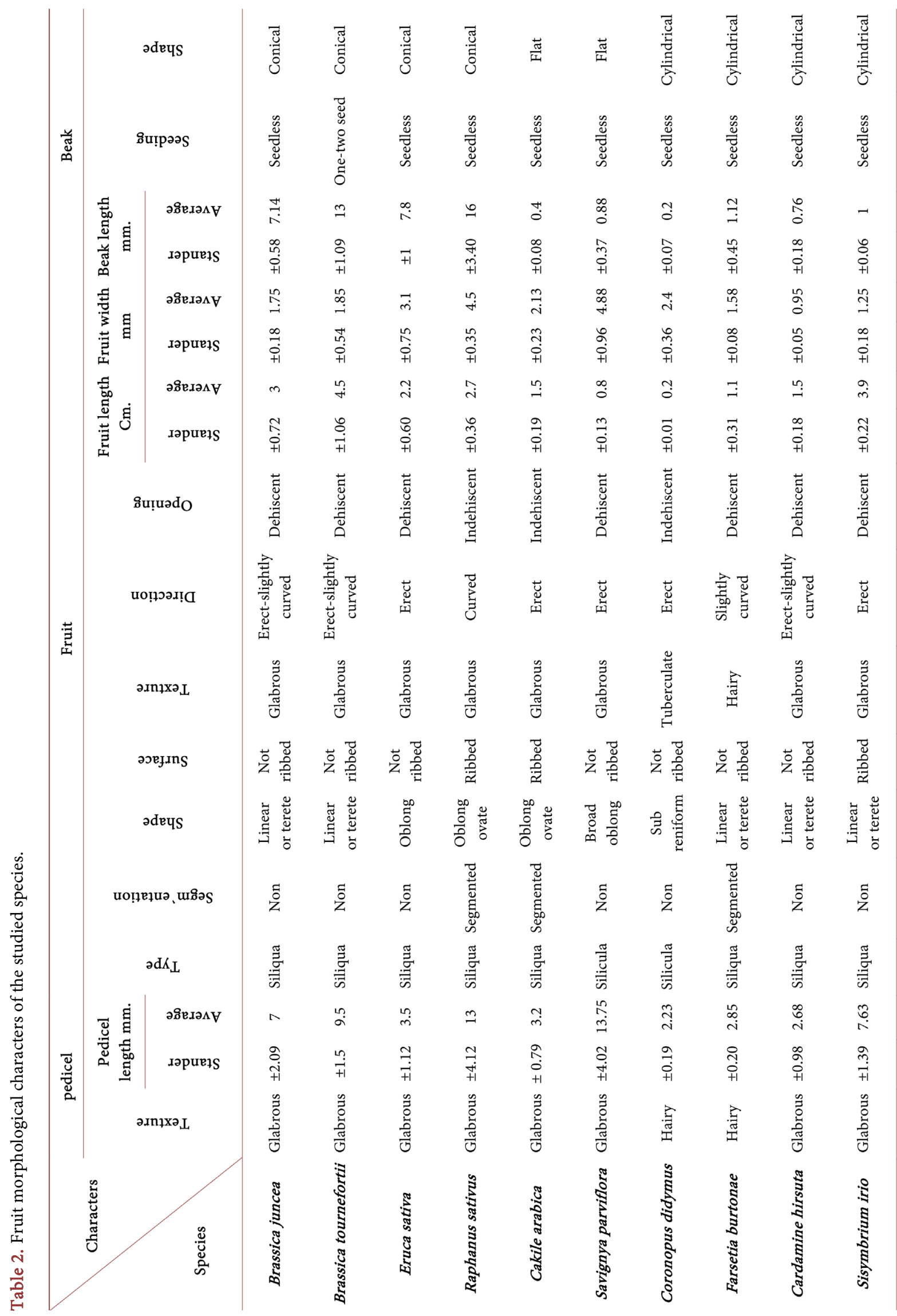




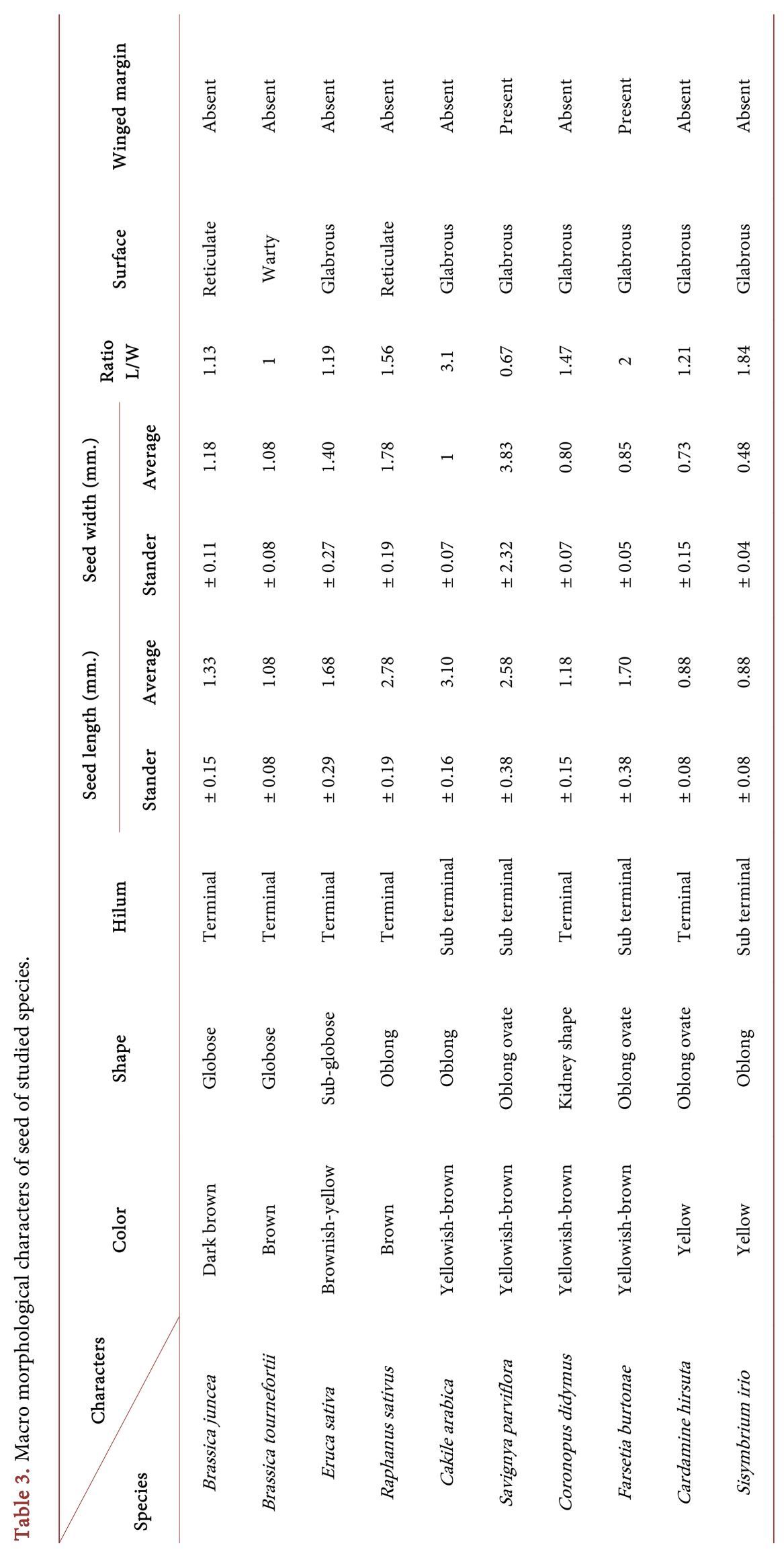




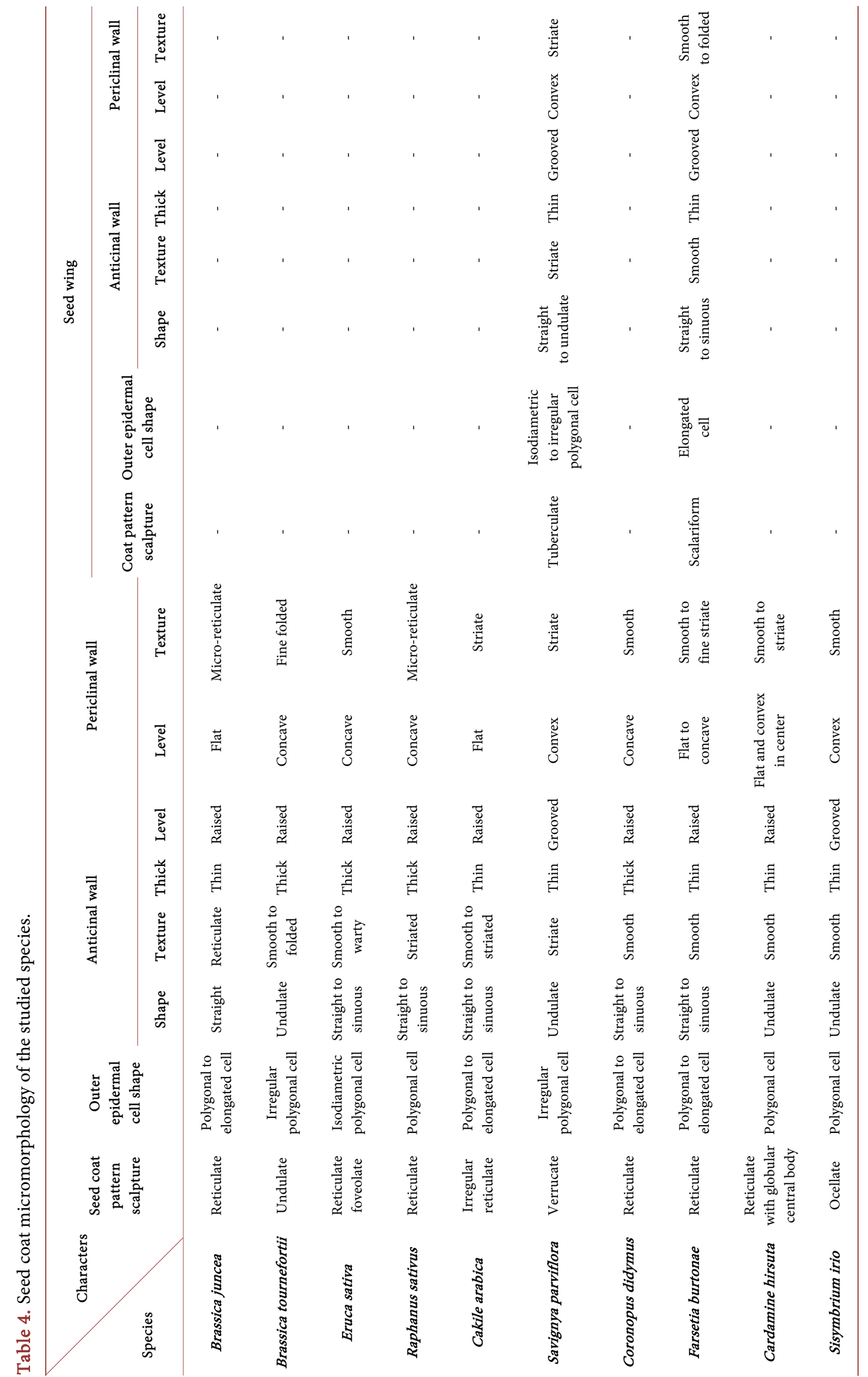


Table 5. Characters list for the numerical analysis of the studied species of Brassicaceae.

\begin{tabular}{|c|c|c|}
\hline \multirow{2}{*}{ Pedicel } & Texture & 1- Glabrous [1]/Hairy [2]. \\
\hline & Length & 2- 2 - $5 \mathrm{~mm} .[1] / 6-10 \mathrm{~mm} .[2] /$ more than $10 \mathrm{~mm} .[3]$ \\
\hline \multirow{12}{*}{ Fruit } & Type & 3- Siliqua [1]/Silicula [2]. \\
\hline & Segmentation & 4- Segmented [1]/Non-segmented [2]. \\
\hline & Shape & 5- Linear or terete [1]/Oblong [2]/Subreniform [3]. \\
\hline & Surface & 6- Ribbed [1]/Not ribbed [2]. \\
\hline & texture & 7- Glabrous [1]/Tuberculate [2]/Hairy [3]. \\
\hline & Direction & 8- Erect [1]/Erect to slightly curved [2]/Curved [3]. \\
\hline & Opening & 9- Dehiscent [1]/Indehiscent [2]. \\
\hline & Length & 10- $0.1-0.9 \mathrm{~cm} .[1] / 1-2 \mathrm{~cm} .[2] / 2.1-3 \mathrm{~cm} .[3] / 3.1-4 \mathrm{~cm}[4] / 4.1-5 \mathrm{~cm} \mathrm{[5]}$. \\
\hline & Width & 11- $0.1-0.9 \mathrm{~cm} .[1] / 1-2 \mathrm{~cm} .[2] / 2.1-3 \mathrm{~cm} .[3] / 3.1-4 \mathrm{~cm}[4] / 4.1-5 \mathrm{~cm} \mathrm{[5].}$ \\
\hline & Beak length & 12- Less than $1 \mathrm{~mm}$. [1]/1 - $4 \mathrm{~mm}$. [2]/5 - $7 \mathrm{~mm}$. [3]/More than $7 \mathrm{~mm}$. [4]. \\
\hline & Beak seeding & 13- Seedless [1]/one-two seed [2]. \\
\hline & Beak shape & 14- Conical [1]/Cylindrical [2]/Flate [3]. \\
\hline \multirow{15}{*}{ Seed } & Color & 15- Brown [1]/Dark brown [2]/Yellowish brown [3]/Yellow [4]. \\
\hline & Shape & 16- Globose [1]/Sub-globose [2]/Oblong [3]/Kidney shape [4]. \\
\hline & Hilum & 17- Terminal [1]/Sub terminal [2]. \\
\hline & Length & 18- Less than $1 \mathrm{~mm}[1] / 1-2 \mathrm{~mm} \mathrm{[2]/more} \mathrm{than} 2 \mathrm{~mm} \mathrm{[3].}$ \\
\hline & Width & 19- 18 -Less than $1 \mathrm{~mm}[1] / 1-2 \mathrm{~mm} \mathrm{[2]/more} \mathrm{than} 2 \mathrm{~mm}[3]$. \\
\hline & Surface & 20- Reticulate [1]/Warty [2]/Glabrous [3]. \\
\hline & Margin & 21- Winged [1]/Not winged [2]. \\
\hline & Seed coat pattern scalpture & 22- Reticulate [1]/Undulate [2]/Verrucate [3]/Ocellate [4]. \\
\hline & Outer epidermal cell shape & $\begin{array}{l}\text { 23- Polygonal to elongated cell [1]/Irregular polygonal cell [2]/Isodiametric polygonal cell [3]/ } \\
\text { polygonal cell [4]. }\end{array}$ \\
\hline & Anticinal wall shape & 24- Straight [1]/Undulate [2]/Straight to sinuous [3]. \\
\hline & Anticinal wall texture & $\begin{array}{l}\text { 25- Reticulate [1]/Smooth [2]/Striate [3]/Smooth to folded [4]/Smooth to warty [5]/ } \\
\text { Smooth to striated [6]. }\end{array}$ \\
\hline & Anticinal wall thickening & 26- Thick [1]/Thin [2]. \\
\hline & Anticinal wall level & 27- Raised [1]/Grooved [2]. \\
\hline & Periclinal wall level & 28- Flat [1]/Concave [2]/Convex [3]/Flat to concave [4]/Flat to convex [5]. \\
\hline & Periclinal wall texture & 29- Micro reticulate [1]/Fin folded [2]/Smooth [3]/Striate [4]/Smooth to striate [5]. \\
\hline \multirow{5}{*}{ Seed wing } & coat pattern scalpture & 30- Tuberculate [1]/Scalariform [2]. \\
\hline & Outer epidermal cell shape & 31- Isodiametric to irregular polygonal [1]/Elongated [2]. \\
\hline & Anticinal wall shape & 32- Straight to undulate [1]/Straight to sinuous [2]. \\
\hline & Anticinal wall texture & 33- Striate [1]/Smooth [2]. \\
\hline & Periclinal wall texture & 34-Striate [1]/Smooth to fold [2]. \\
\hline
\end{tabular}


Table 6. Data matrix of morphological characters listed in Table 5.

\begin{tabular}{|c|c|c|c|c|c|c|c|c|c|c|}
\hline $\begin{array}{l}\text { Species } \\
\text { Characters }\end{array}$ & $\begin{array}{c}\text { Brassica } \\
\text { juncea }\end{array}$ & $\begin{array}{c}\text { Brassica } \\
\text { tournefortii }\end{array}$ & $\begin{array}{l}\text { Eruca } \\
\text { sativa }\end{array}$ & $\begin{array}{l}\text { Raphanus } \\
\text { sativus }\end{array}$ & $\begin{array}{c}\text { Cakile } \\
\text { arabica }\end{array}$ & $\begin{array}{l}\text { Savignya } \\
\text { parviflora }\end{array}$ & $\begin{array}{l}\text { Coronopus } \\
\text { didymus }\end{array}$ & $\begin{array}{l}\text { Farsetia } \\
\text { burtonae }\end{array}$ & $\begin{array}{l}\text { Cardamine } \\
\text { hirsuta }\end{array}$ & $\begin{array}{c}\text { Sisymbrium } \\
\text { irio }\end{array}$ \\
\hline al & 1 & 1 & 1 & 1 & 1 & 1 & 2 & 2 & 1 & 1 \\
\hline a2 & 2 & 2 & 1 & 3 & 1 & 3 & 1 & 1 & 1 & 2 \\
\hline a3 & 1 & 1 & 1 & 1 & 1 & 2 & 2 & 1 & 1 & 1 \\
\hline $\mathrm{a} 4$ & 2 & 2 & 2 & 1 & 1 & 2 & 2 & 1 & 2 & 2 \\
\hline a5 & 1 & 1 & 2 & 2 & 2 & 2 & 3 & 1 & 1 & 1 \\
\hline a6 & 2 & 2 & 2 & 1 & 1 & 2 & 2 & 2 & 2 & 1 \\
\hline a7 & 1 & 1 & 1 & 1 & 1 & 1 & 2 & 3 & 1 & 1 \\
\hline a8 & 2 & 2 & 1 & 3 & 1 & 1 & 1 & 2 & 2 & 1 \\
\hline a9 & 1 & 1 & 1 & 2 & 2 & 1 & 2 & 1 & 1 & 1 \\
\hline a10 & 3 & 5 & 3 & 3 & 2 & 1 & 1 & 2 & 2 & 4 \\
\hline a11 & 2 & 2 & 4 & 5 & 3 & 5 & 3 & 2 & 1 & 2 \\
\hline a12 & 4 & 4 & 3 & 4 & 1 & 1 & 1 & 2 & 1 & 2 \\
\hline a13 & 1 & 2 & 1 & 1 & 1 & 1 & 1 & 1 & 1 & 1 \\
\hline a14 & 1 & 1 & 1 & 1 & 3 & 3 & 2 & 2 & 2 & 2 \\
\hline a15 & 1 & 2 & 3 & 1 & 3 & 3 & 3 & 3 & 4 & 4 \\
\hline a16 & 1 & 1 & 2 & 3 & 3 & 3 & 4 & 3 & 3 & 3 \\
\hline a17 & 1 & 1 & 1 & 1 & 2 & 2 & 1 & 2 & 1 & 2 \\
\hline a18 & 2 & 2 & 2 & 3 & 3 & 3 & 2 & 2 & 1 & 1 \\
\hline a19 & 2 & 2 & 2 & 2 & 2 & 3 & 1 & 1 & 1 & 1 \\
\hline $\mathrm{a} 20$ & 1 & 2 & 3 & 1 & 3 & 3 & 3 & 3 & 3 & 3 \\
\hline a21 & 2 & 2 & 2 & 2 & 2 & 1 & 2 & 1 & 2 & 2 \\
\hline a22 & 1 & 2 & 1 & 1 & 1 & 3 & 1 & 1 & 1 & 4 \\
\hline a23 & 1 & 2 & 3 & 4 & 1 & 2 & 1 & 1 & 4 & 4 \\
\hline a24 & 1 & 2 & 3 & 3 & 3 & 2 & 3 & 3 & 2 & 2 \\
\hline a25 & 1 & 4 & 5 & 3 & 6 & 3 & 2 & 2 & 2 & 2 \\
\hline a26 & 2 & 1 & 1 & 1 & 2 & 2 & 1 & 2 & 2 & 2 \\
\hline $\mathrm{a} 27$ & 1 & 1 & 1 & 1 & 1 & 2 & 1 & 1 & 1 & 2 \\
\hline a28 & 1 & 2 & 2 & 2 & 1 & 3 & 2 & 4 & 5 & 3 \\
\hline a29 & 1 & 2 & 3 & 1 & 4 & 4 & 3 & 5 & 5 & 3 \\
\hline $\mathrm{a} 30$ & 0 & 0 & 0 & 0 & 0 & 1 & 0 & 2 & 0 & 0 \\
\hline a31 & 0 & 0 & 0 & 0 & 0 & 1 & 0 & 2 & 0 & 0 \\
\hline a32 & 0 & 0 & 0 & 0 & 0 & 1 & 0 & 2 & 0 & 0 \\
\hline a33 & 0 & 0 & 0 & 0 & 0 & 1 & 0 & 2 & 0 & 0 \\
\hline a34 & 0 & 0 & 0 & 0 & 0 & 1 & 0 & 2 & 0 & 0 \\
\hline
\end{tabular}




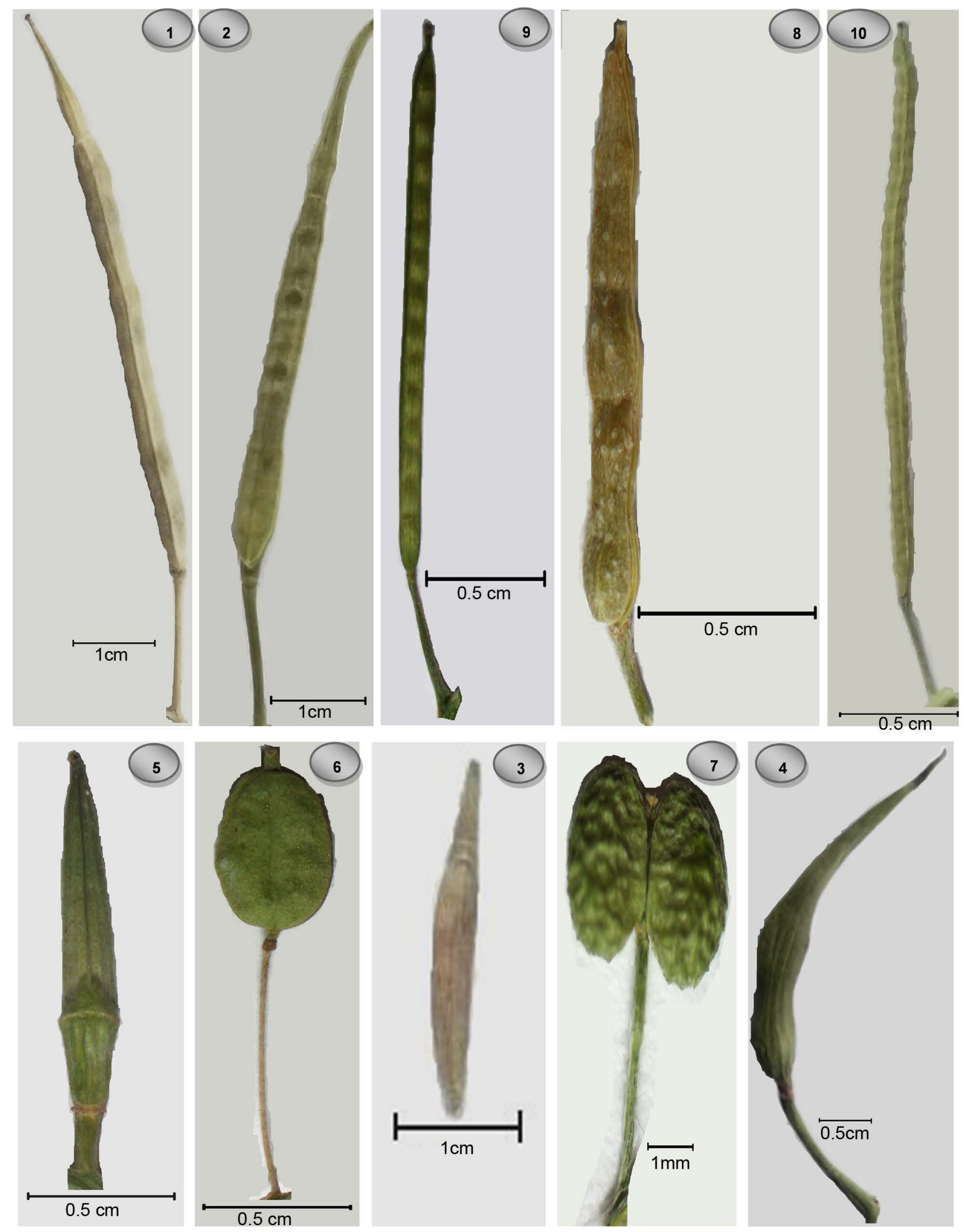

Figure 1. Fruit morphology of 10 species of Brassicaceae as revealed by light microscope: 1. Brassica juncea; 2. Brassica tournefortii, 3. Eruca sativa, 4. Raphanus sativus, 5. Cakile Arabica, 6. Savignya parviflora, 7. Coronopus didymus, 8. Farsetia burtonae, 9. Cardamine hirsute, 10. Sisymbrium irio. 

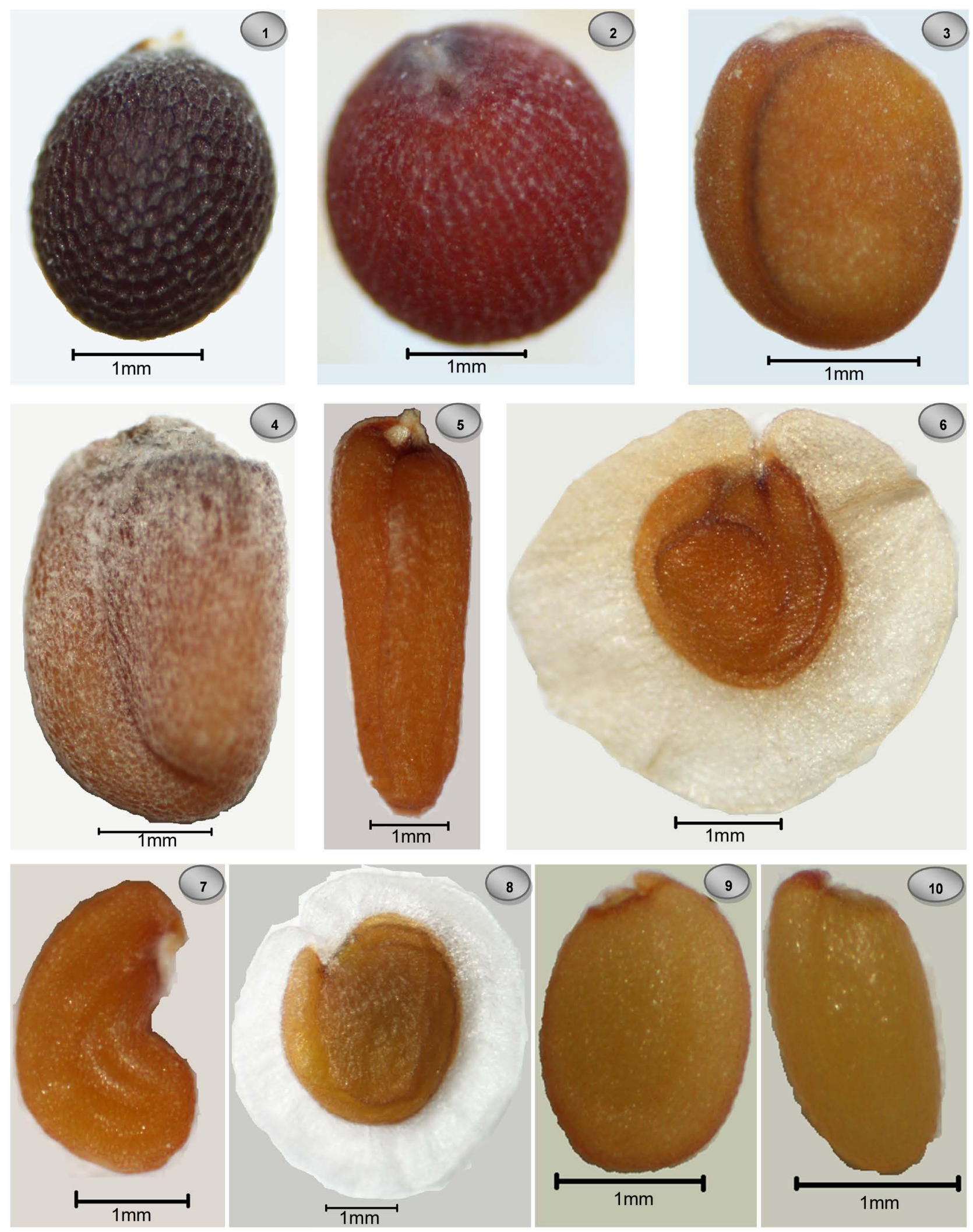

Figure 2. Seed morphology of 10 species of Brassicaceae as revealed by light microscope: 1. Brassica juncea; 2. Brassica tournefortii, 3. Eruca sativa, 4. Raphanus sativus, 5. Cakile Arabica, 6. Savignya parviflora, 7. Coronopus didymus, 8. Farsetia burtonae, 9. Cardamine hirsute, 10. Sisymbrium irio. 

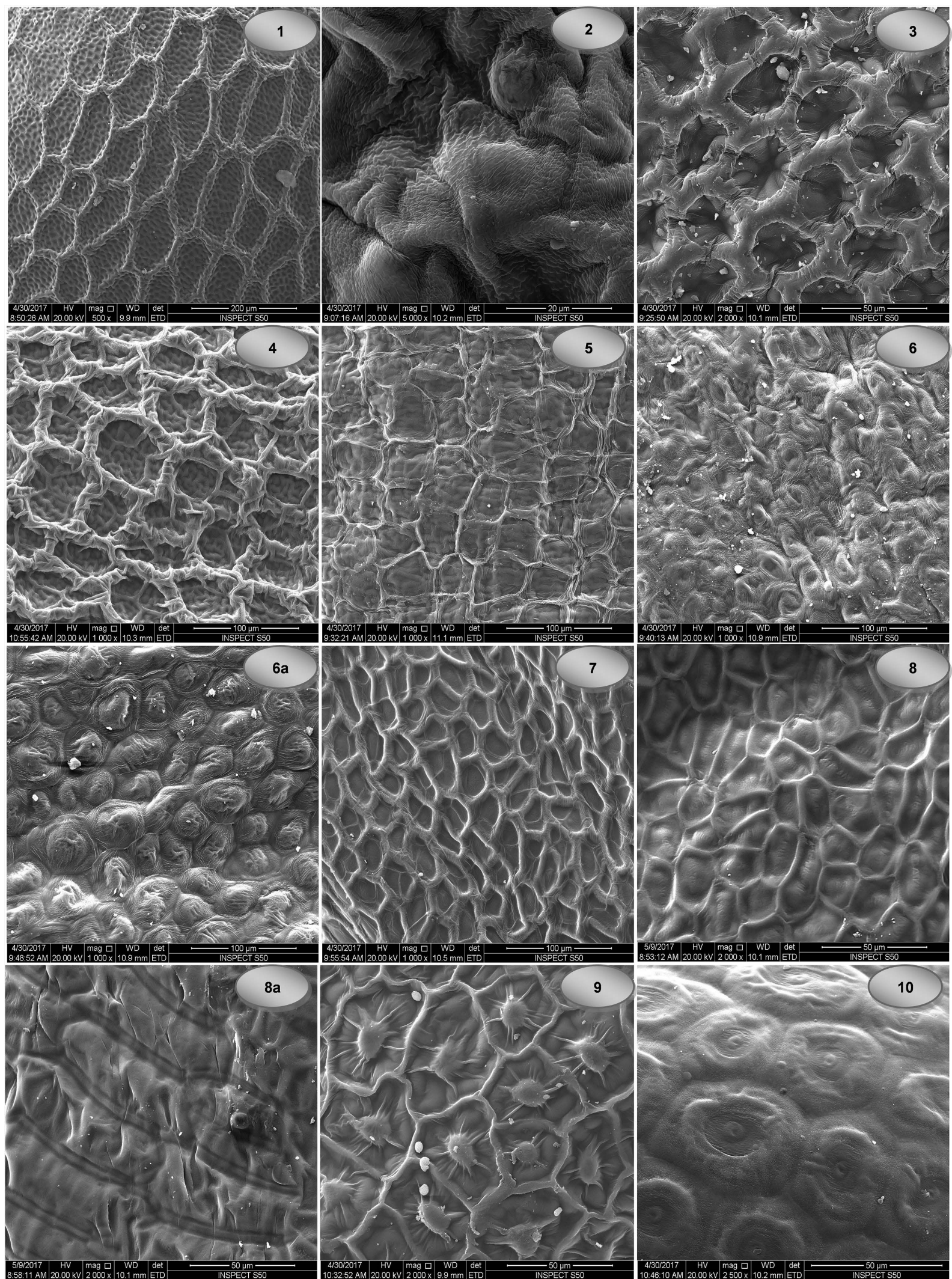

Figure 3. Scanning electron microscope micrographs of seeds (a), Surface sculpture of wing margin; 1. Brassica juncea; 2 . Brassica tournefortii, 3. Eruca sativa, 4. Raphanus sativus, 5. Cakile Arabica, 6. Savignya parviflora, 7. Coronopus didymus, 8. Farsetia burtonae, 9. Cardamine hirsute, 10. Sisymbrium irio. 


\subsubsection{Fruit Direction and Opening}

The most species of family Brassicaceae are characterized by erect and dehiscent fruit. In the studied species four spices [Eruca sativa, Savignya parviflora, Cardamine hirsute and Sisymbrium irio] are erect and dehiscent, while erect and indehiscent in Cakile arabica and Coronopus didymus. Erect to slightly curved and dehiscent in Brassica juncea, Brassica tournefortii and Farsetia burtonae. Curved and indehiscent in Raphanus sativus only.

\subsubsection{Fruit Size}

The size of fruit in the studied species are different from very long (more than 3 $\mathrm{cm}$.), long $(1-3 \mathrm{~cm}$.) and short (less than $1 \mathrm{~cm}$.) in length or narrow (less than 2 $\mathrm{mm}$.) or wide (more than $2 \mathrm{~mm}$.) in width. Very long and narrow in Brassica tournefortii and Sisymbrium irio; long and narrow in Brassica juncea, Farsetia burtonae and Cardamine hirsute while long and wide in Eruca sativa, Raphanus sativus and Cakile arabica. Short and wide in Savignya parviflora and Coronopus didymus.

\subsubsection{Beak Characters}

The size of the beak ranged from $0.2 \mathrm{~mm}-16 \mathrm{~mm}$ in length. The smallest size $0.2 \mathrm{~mm}$ present in Coronopus didymus, while the longest $16 \mathrm{~mm}$ present in Raphanus sativus. The beak is seedless in all studied species except in Brassica tournefortii have one or two seed. The shape of the beak in the studied species recorded three types, conical in Brassica juncea, Brassica tournefortii, Eruca sativa and Raphanus sativus, flat in Cakile Arabica and Savignya parviflora, cylindrical in the reminder.

\subsection{Seed Characters}

\subsubsection{Seed Color}

The color of seeds is highly important for distinguish between different species. The seed color in studied species varied from yellow in Cardamine hirsute and Sisymbrium irio; yellowish-brown in Cakile arabica, Savignya parviflora, Coronopus didymus and Farsetia burtonae; brownish-yellow in Eruca sativa and brown in the remainder species.

\subsubsection{Seed Shape}

Seed shape of the studied species recorded four types; globose in Brassica juncea and Brassica tournefortii; sub-globose in Eruca sativa; kidney shape in Coronopus didymus, oblong ovate in Savignya parviflora, Farsetia burtonae and Cardamine hirsute, oblong in the reminder.

\subsubsection{Seed Hilum}

The hilum of seed in most studied species is terminal except in Cakile arabica, Savignya parviflora, Farsetia burtonae, and Sisymbrium irio are sub terminal.

\subsubsection{Seed Size}

Seed length and width varied among the studied species; it ranged from $0.8 \mathrm{~mm}$ - 
$3.1 \mathrm{~mm}$ length $\times 3.8 \mathrm{~mm}-0.48 \mathrm{~mm}$ width. The longest seed have size $3.1 \mathrm{~mm} \times 1$ $\mathrm{mm}$ present in Cakile arabica, while the smallest seed $(0.88 \mathrm{~mm} \times 0.48 \mathrm{~mm})$ present in Sisymbrium irio.

\subsubsection{Seed Surface}

The seed surface of the studied species recorded four types; reticulate in Brassica juncea and Raphanus sativus; warty in Brassica tournefortii; glabrous in the reminder.

\subsubsection{Seed Margin}

The seed are winged in two species only [Savignya parviflora and Farsetia burtonae], and not winged in the rest studied species.

\subsubsection{Seed Coat Pattern Sculpture: Table 4 \& Figure 3}

Examination by scanning electron microscope on the studied species shows four different types of seed coat pattern; the reticulate is the main types in which seven species belong to it:

1) Reticulate, with four subtypes:

a) Regular reticulate recorded in Brassica juncea, Raphanus sativus, Coronopus didymus and Farsetia burtonae.

b) Reticulate-foveolate in Eruca sativa.

c) Irregular reticulate present in Cakile arabica.

d) Reticulatewith globular central body in Cardamine hirsute.

2) Undulate in Brassica tournefortii.

3) Verrucate in Savignya parviflora.

4) Ocellate in Sisymbrium irio.

\subsubsection{Shape of Outer Epidermal Cell}

Outer epidermal cells can be of considerable important value for systematics. The outer epidermal cells varied from polygonal to elongated cell in Brassica juncea, Cakile arabica, Coronopus didymus and Farsetia burtonae, irregular poly gonal cell in Brassica tournefortii and Savignya parviflora; isodiametric polygonal cells in Eruca sativa; polygonal cell in the reminder species.

\subsubsection{Anticlinal Wall}

The characters of anticlinal wall can be used for identification and differentiate the different species. The shape of anticlinal wall recorded three types in the studied species; undulate in Brassica tournefortii, Savignya parviflora, Cardamine hirsute and Sisymbrium irio; straight in Brassica juncea only and straight to sinuous in the reminder species. The main types for the texture of the anticlinal wall is smooth, but it smooth to fold in Brassica tournefortii; smooth to warty in Eruca sativa and smooth to striated in Cakile arabica. The texture is reticulate in Brassica juncea and striated in Raphanus sativus. The anticinal wall varied from thin to thick, it is thick in Brassica tournefortii, Eruca sativa, Raphanus sativus and Coronopus didymus; while thin in the reminder species. All the studied 
species with raised anticlinal wall except in Savignya parviflora and Sisymbrium irio are grooved.

\subsubsection{Periclinal Wall}

The characters of the outer periclinal cell wall can be good diagnostic characters. The present study recorded five types for the shape of Periclinal wall; flat in Brassica juncea and Cakile arabica; flate to concave in Farsetia burtonae; flat and convex in center in Cardamine hirsute; convex in Savignya parviflora and Sisymbrium irio; concave in the rest of species. The texture of Periclinal wall have five types; micro-reticulate in Brassica juncea and Raphanus sativus, fine folded in Brassica tournefortii; striate in Cakile arabica and Savignya parviflora; smooth to fine striate in Farsetia burtonae; smooth in the rest studied species.

\subsubsection{Seed Wing}

There are two seeds from the studied species are winged, the coat pattern sculpture for these seeds are tuberculate in Savignya parviflora and scalariform in Farsetia burtonae. The outer epidermal cell shape is isodiametric to irregular polygonal in Savignya parviflora while elongated in Farsetia burtonae. The shape of anticinal wall is straight to undulate in Savignya parviflora while straight to sinuous in Farsetia burtonae. The texture of anticinal wall is striate in Savignya parviflora and smooth in Farsetia burtonae. The thickening and level of anticinal wall for the two speces are thin and grooved. The shape of Periclinal wall is convex in the two winged species, but the texture is striate in Savignya parviflora while smooth to folded in Farsetia burtonae.

\section{Numerical Analysis}

The fruit and seed morphology characters of the studied species obtained by light and scanning electron microscope 34 characters (14 characters for fruit and 20 characters for seed) were used for numerical analysis.

The cluster analysis obtained from fruit characters only (Figure 4(a)) showed that species were grouped into two major clusters and each cluster divided into two groups, the first cluster I consisted of five species: Coronopus didymus and Farsetia burtonae recorded in group I while Cardamine hirsute, Cakile arabica and Sisymbrium irio present in group II. The cluster II comprised five species: Raphanus sativus (group I) and Brassica juncea, Eruca sativa, Brassica tournefortii and Savignya parviflora (group II).

The results obtained from seed characters only (Figure 4(b)) also divided the studied species into two main clusters and two groups. Cluster I contained Savignya parviflora and Farsetia burtonae. While cluster II consisted of eight species present in two groups; Cardamine hirsute, Raphanus sativus, Coronopus didymus, Eruca sativa and Cakile arabica in group I and Brassica juncea, Brassica tournefortii and Sisymbrium irio in group II.

The results obtained from combined of fruit and seed characters (Figure 4(c)) divided the species into two main clusters and two groups. Cluster I contained 


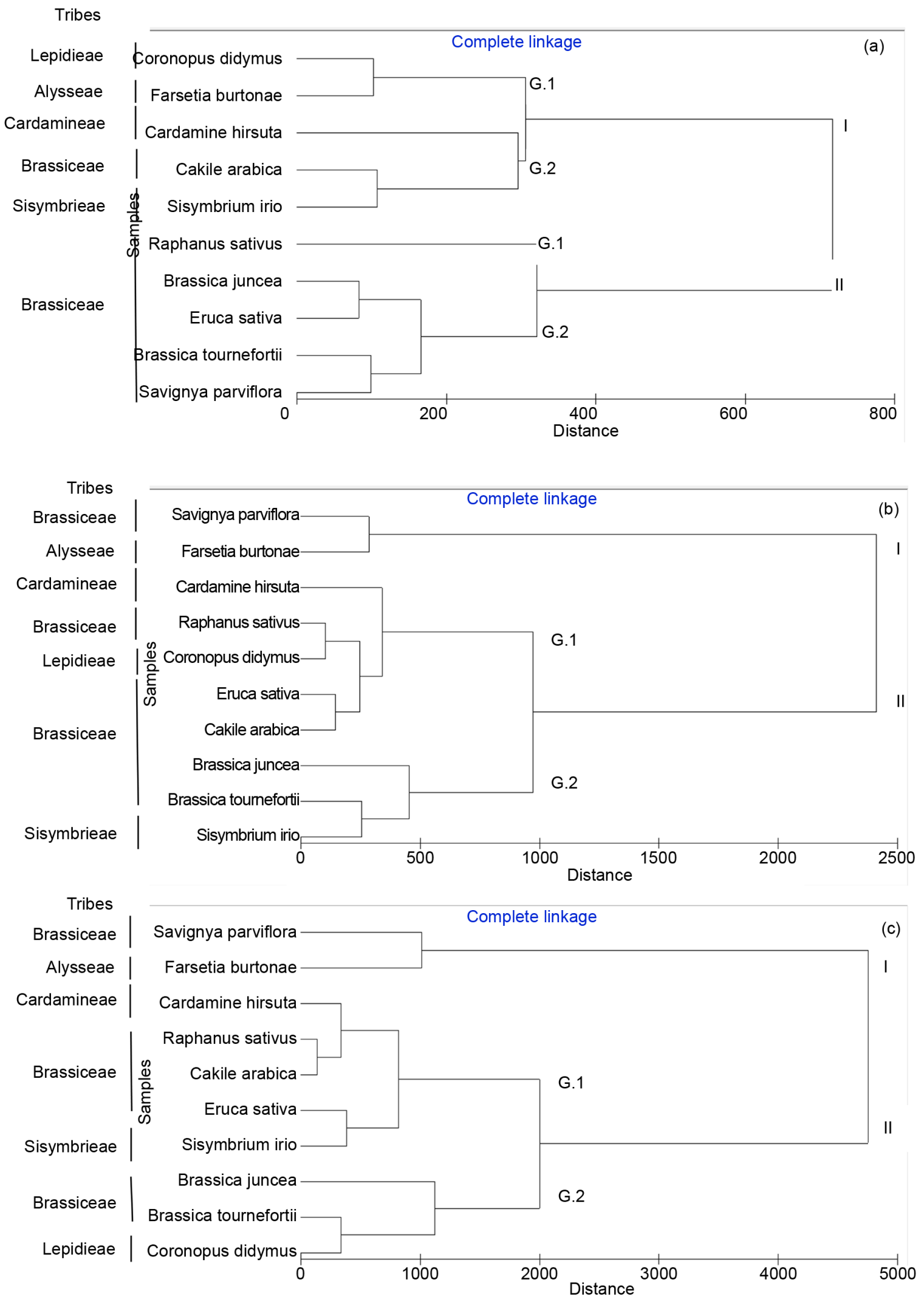

Figure 4. Dendrograms showing the interrelationships between ten species of Brassicaceae based on 34 characters, (I) cluster one, (II) cluster two, (G1) group one, (G2) group two, (a) fruit characters, (b) seed characters, (c) combined fruit and seed characters by using PRIMER Program. 
Savignya parviflora and Farsetia burtonae. While cluster II consisted of eight species present in two groups; Cardamine hirsute, Raphanus sativus, Cakile arabica, Eruca sativa and Sisymbrium irio in group I and Brassica juncea, Brassica tournefortii and Coronopus didymus in group II.

\section{Discussion}

The tribal classification of Brassicaceae has long been problematic and not well understood phylogenetically because of the traditionally used few characters as cotyledons in the embryo, fruit characters, number of rows of seeds in each locule, trichome type, and features of the nectarines etc. to delimit different tribes of the family Brassicaceae [23] [63]. In the present study, the species are recorded in five tribes (Alysseae, Lepideae, Sisymbrieae, Cardamineae, Brassiceae) [15].

The tribe Alysseae DC. As delimited by [15] [64] are polyphyletic. It consists of approximately 280 species, the Farsetia species put in different tribes in different studies; [5] put it in tribe Hesperideae under subtribe Malcolmiinae while [7] placead the Farsetia species with Lobularia in tribe Alyssineae, [10] put it in tribe Arabideae. Recently [15] put the species Farsetia in tribe Alysseae as [8]. The tribe has recently been studied phylogenetically as [65] [66]. The position of Alysseae relative to the other tribes varied in different studies; [20] put the tribe with tribe Brassiceae in lineage II, while [63] say the tribe appeared either related to Erysimum or unrelated to any tribe. [67] found the tribe related to the Noccaeeae, while [68] it grouped together with the tribes Chorisporeae, Hesperideae, and Malcolmieae. In the present study tribe Alysseae (Farsetia burtonae) are placed with tribe Lepideae (Coronopus didymus) in the cluster result from fruit characters only, this differ from the traditional classification which separate them into different tribes or different groups, but it agree with recent molecular studies as [27] which put the two tribes in the same lineage. While in the clusters results from seed or seed and fruit characters the tribe Alysseae (Farsetia burtonae) are placed with species of tribe Brassiceae (Savignya parviflora), this agree with some molecular studies as [27] [69].

The tribe Lepideae consists of three to five genera and over 240 species, [15] [70]. It is polyphyletic. Some genetic studies as done on the tribes, [27] [69] [71] [72] [73]. In the present study the tribe Lepideae (Coronopus didymus) are placed with some species of tribe Brassiceae, this agree with some traditional studies as [5] which put them in the same tribe but in different sub-tribes, or placed with species of tribe Alysseae (Farsetia burtonae) in the same group.

The tribe Sisymbrieae was recognized with 70 genera and 400 species according to [8] [74] but molecular data as, [18] [75] [76] [77], supported the removal of many of its component genera to other tribes. The tribe is monophyletic and is sister to the Schizopetaleae [20] or the Brassiceae [18] [75]. In the present study the tribe Sisymbrieae (Sisymbrium irio) found together with species from tribe Brassiceae, this agrees with [5] [18] [27] [69] [75].

[9] presented a phylogenetic network and indicated close relationships of 
Sisymbrieae with Arabideae and Lepidieae. [78] [79] have shown that the boundaries between the tribes Lepidieae, Lunarieae, Sisymbrieae, Euclidieae, and Alysseae are highly artificial. The results from previous studies of phylogenetic relationships [71] [72] [73] demonstrated a close relationship among the tribes Sisymbrieae, Lepidieae and Arabideae. [70] indicated that the tribes Arabideae, Lepidieae and Sisymbrieae are polyphyletic.

The tribe Cardamineae DC is monophyletic. The tribe has been subjected to several molecular studies as; [80] [81] [82] [83] [84] that support its monophyly. The position of Cardamineae relative to the other tribes is done by some studies as, [27] [69]. The study put the tribe Cardamineae with tribe Lepidieae and tribe Alysseae in the same lineage. In the present study the tribe Cardamineae (Cardamine hirsute) placed together in the same group with some species of tribe Brassiceae and tribe Sisymbrieae in all clusters, this agree with [5].

The tribe Brassiceae DC is consider monophyletic according to some molecular studies as [19] [85] [86]. This tribe was subjected to extensive molecular studies, [20] [63] [67] [69] [87] [88]. In the present study the most species of tribe Brassieae are placed together but some species present with different tribes. This results support the Brassiceae to be heterogenous.

\section{Conclusion}

The fruit and seed coat characters are very important characters that can be used for identification and differentiate between the different tribes and also between species belong to the same genera. Most tribes of Brassicaceae are polyphyletic, and some are related to each other's as Lepidieae, Alyssieae and Sisymbrieae. The results indicate the tribe Brassiceae to be heterogenous.

\section{Acknowledgements}

Author is grateful to the staff of Institute for Research and Medical Consultation (IRMC) in the University of Imam Abdulrahman Bin Faisal for carry out the Scanning Electron Microscope (SEM). Also I would like to express my sincere appreciation to the research units of college Science research for giving me the opportunity to conduct the practical part research.

\section{References}

[1] Warwick, S.I., Francis, A. and Al-Shehbaz, I.A. (2006) Brassicaceae: Species Checklist. Plant Systematics and Evolution, 259, 249-258.

https://doi.org/10.1007/s00606-006-0422-0

[2] Chaudhary, S.A. (1999) Flora of the Kingdom of Saudi Arabia. Ministry of Agriculture and Water, Riyad, Kingdom of Saudi Arabia, Volume 1, 462-523.

[3] Mandaville, J.P. (1990) Flora of Eastern Saudi Arabia. Kegan Paul International, London\&N.Y. jointly with the National Commission for Wildlife Conservation and Development, Riyadh, 130-155.

[4] Bentham, G. and Hooker, J.D. (1862) Genera Plantarum. Reeve, London, Vol. 1, 57-102. 
[5] Prantl, K. (1891) Cruciferae. In: Engler, A. and Prantl, K., Eds., Die Natürlichen Pflanzenfamilien, Engelmann, Leipzig, 145-208.

[6] Hayek, A.V. (1911) Entwurf eines Cruciferae-Systems auf Pflogenetischer Grundlage. Beihefte zum Botanischen Centralblatt, 27, 127-335.

[7] Post, G. (1932) Flora of Syria, Palestine and Sinai. American Press, Beirut, Vol. 1, 500-574.

[8] Schulz, O.E. (1936) Cruciferae. In: Engler, A. and Prantl, K., Eds., Die natürlichen Pflanzenfamilien, Vol.17B, Engelmann, Leipzig, 227-658.

[9] Janchen, E. (1942) Das system der Cruciferen. Oesterreichische botanische Zeitschrift, 91, 1-18. https://doi.org/10.1007/BF01257342

[10] Zohary, M. (1966) Clypeola L. In: Zohary, M., Ed., Flora Palaestina, Vol. 1, Israel Academy of Sciences and Humanities, Jerusalem, 289-294.

[11] Davis, P.H. (1975) Flora of Turkey Edinburgh. Edinburgh University Press, Edinburgh, 158-174.

[12] Avetisian, V.E. (1976) Some Modifications of the System of the Family Brassicaceae. Botaničeskij Zhurnal, 61, 1198-1203.

[13] Avetisian, V.E. (1983) The System of the Family Brassicaceae. Botaničeskij Zhurnal, 68, 1297-1305.

[14] Al-Shehbaz, I.A. (1984) The Tribes of Cruciferae (Brassicaceae) in the Southeastern United States. Journal of the Arnold Arboretum, 65, 343-373.

[15] Al-Shehbaz, I.A., Beilstein, M.A. and Kellogg, E.A. (2006) Systematics and Phylogeny of the Brassicaceae: An Overview. Plant Systematics and Evolution, 259, 89-120. https://doi.org/10.1007/s00606-006-0415-Z

[16] Zunk, K., Mummenhoff, K. and Hurka, H. (1999) Phylogenetic Relationships in Tribe Lepidieae (Brassicaceae) Based on Chloroplast DNA Restriction Site Variation. Canadian Journal of Botany, 77, 1504-1512.

[17] Bailey, C.D., Price, R.A. and Doyle, J.J. (2002) Systematics of the Halimolobine Brassicaceae: Evidence from Three Loci and Morphology. Systematic Botany, 27, 318-332.

[18] Koch, M., Al-Shehbaz, I.A. and Mummenhoff, K. (2003) Molecular Systematics, Evolution, and Population Biology in the Mustard Family (Brassicaceae). Annals of the Missouri Botanical Garden, 90, 151-171. https://doi.org/10.2307/3298580

[19] Warwick, S.I. and Sauder, C. (2005) Phylogeny of Tribe Brassiceae (Brassicaceae) Based on Chloroplast Restriction Site Polymorphisms and Nuclear Ribosomal Internal Transcribed Spacer and Chloroplast trnL Intron Sequences. Canadian Journal of Botany, 83, 467-483. https://doi.org/10.1139/b05-021

[20] Beilstein, M.A., Al-Shehbaz, I.A. and Kellogg, E.A. (2006) Brassicaceae Phylogeny and Trichome Evolution. American Journal of Botany, 93, 607-619. https://doi.org/10.3732/ajb.93.4.607

[21] Warwick, S.I., Sauder, C.A., Al-Shehbaz, I.A. and Jacquemoud, F. (2007) Phylogenetic Relationships in the Tribes Anchonieae, Chorisporeae, Euclidieae, and Hesperideae (Brassicaceae) Based on Nuclear Ribosomal Its DNA Sequences. Annals of the Missouri Botanical Garden, 94, 56-78. https://doi.org/10.3417/0026-6493(2007)94[56:PRITTA]2.0.CO;2

[22] German, D.A. and Al-Shehbaz, I.A. (2008) Five Additional Tribes (Aphragmeae, Biscutelleae, Calepineae, Conringieae and Erysimeae) in the Brassicaceae (Cruciferae). Harvard Papers in Botany, 13, 165-170. https://doi.org/10.3100/1043-4534(2008)13[165:FATABC]2.0.CO;2 
[23] Warwick, S.I., Sauder, C.A., Mayer, M.S. and Al-Shehbaz, I.A. (2009) Phylogenetic Relationships in the Tribes Schizopetaleae and Thelypodieae (Brassicaceae) Based on Nuclear Ribosomal ITS Region and Plastid ndhF DNA Sequences. Botony, 87, 961-985. https://doi.org/10.1139/B09-051

[24] Franzke, A., German, D., Al-Shehbaz, I.A. and Mummenhoff, K. (2009) Arabidopsis Family Ties: Molecular Phylogeny and Age Estimates in the Brassicaceae. Taxon, 58, 425-437.

[25] Mohamed, A.H. (2009) Molecular Systematic of Some Brassicaceae Taxa in Egypt Based on Electrophoretic Isoenzymes Pattern and RAPD Markers. Australian Journal of Basic and Applied Sciences, 3, 1499-1511.

[26] Couvreur, T.L.P., Franzke, A., Al-Shehbaz, I.A., Bakker, F., Koch, M.A. and Mummenhoff, K. (2010) Molecular Phylogenetics, Temporal Diversification and Principles of Evolution in the Mustard Family (Brassicaceae). Molecular Biology and Evolution, 27, 55-71. https://doi.org/10.1093/molbev/msp202

[27] Liu, L., Zhao, B., Tan, D. and Wang, J. (2012) Phylogenetic Relationships of Brassicaceae Species Based on Matk Sequences. Pakistan Journal of Botany, 44, 619-626.

[28] Özüdoğru, B., Akaydın, G., Erik, S., Al-Shehbaz, I. and Mummenhoff, K. (2015) Phylogeny, Diversification and Biogeographic Implications of the Eastern Mediterranean Endemic Genus Ricotia (Brassicaceae). Taxon, 64, 727-740. https://doi.org/10.12705/644.5

[29] Li, Y., Feng, Y., Lv, G.H., Liu, B. and Qi, A. (2015) The Phylogeny of Alyssum (Brassicaceae) Inferred from Molecular Data. Nordic Journal of Botany, 33, 715-721. https://doi.org/10.1111/njb.00588

[30] Heywood, V.H. (1971) Scanning Electron Microscopy. Systematic and Evolutionary Applications. Journal of the Arnold Arboretum, 65, 343-373.

[31] Cole, G.T. and Behnke, H.D. (1975) Electron Microscopy and Plant Systematics. Taxon, 24, 3-15. https://doi.org/10.2307/1218989

[32] Barthlott, W. (1981) Epidermal and Seed Surface Applicability and Some Evolutionary Aspects. Nordic Journal of Botany, 1, 345-355. https://doi.org/10.1111/j.1756-1051.1981.tb00704.x

[33] Barthlott, W. (1984) Microstructural Features of Seed Surface. In: Heywood, V.H. and Moore, D.C., Eds., Current Concepts in Plant Taxonomy, Academic Press, London, 95-105.

[34] Gunn, C.R. (1981) Seed Topography in the Fabaceae. Seed Science and Technology, 9, 737-757.

[35] Zeng, C.L., Wang, J.B., Liu, A.H. and Wu, X.M. (2004) Seed Coat Microsculpturing Changes during Seed Development in Diploid and Amphiploid Brassica Species. nnals of Botany, 93, 555-566. https://doi.org/10.1093/aob/mch080

[36] Musil, A.F. (1948) Distinguishing Species of Brassica by Their Seeds. U.S. Dept. Agr. Washington, D.C. Misc. Pub. No. 643, 35.

[37] Murley, M.R. (1951) Seeds of the Cruciferae of North Eastern America. American Middle Naturalichen, 46, 1-81. https://doi.org/10.2307/2421948

[38] Berggren, G. (1962) Reviews on the Taxonomy of Some Species of the Genus Brassica, Based on their Seeds. Svensk Botanisk Tidskrift, 56, 65-135.

[39] Vaughan, J.G. and Whitehouse, J.M. (1971) Seed Structure and the Taxonomy of Cruciferae. Botanical Journal of the Linnean Society, 64, 383-409. https://doi.org/10.1111/j.1095-8339.1971.tb02153.x

[40] Stork, A.L. (1971) Seed Characters in European Taxa of Malcolmia R. Br. Svensk Botanisk Tidskrift, 65, 283-292. 
[41] Stork, A.L. (1972) Seeds and Seedlings of Malcolmia sens. lat. Svensk Botanisk Tidskrift, 66, 417-433.

[42] Stork, A.L. and Wüest, J. (1978) SEM Studies of Seed Coats in Malcolmia (Cruciferae). Archives des Sciences Physiques et Naturelles, 31, 229-237.

[43] Jonsell, B. (1975) Lepidium L. (Cruciferae) in Tropical Africa. A Morphological, Taxonomical and Phytogeographical Study. Botaniska Notiser, 128, 151-163.

[44] Prasad, K. (1976) Seed Coat Structure and Development in Certain Species of Cruciferae. New Botanist, 3, 95-103.

[45] Mulligan, G.A. and Bailey, L.G. (1976) Seed Coat of Some Brassica and Sinapis Weeds and Cultivated in Canada. Economic Botany, 30, 143-148. https://doi.org/10.1007/BF02862959

[46] Stork, A.L., Songerup, S. and Wüest, J. (1980) Seed Characters in Brassica Section Brassica and Some Related Groups. Candollea, 35, 421-450.

[47] Jonsell, B. (1979) New Taxa of Cruciferae from East Tropical Africa and Madagascar. Botaniska Notiser, 132, 521-535.

[48] Stork, A.L. and Wüest, J. (1980) Morettia DC. (Cruciferae): A Morphological and Taxonomical Study. Boletim da Sociedade Broteriana, 53, 241-273.

[49] Jonsell, B. (1986) A Monograph of Farsetia (Cruciferae). Systematic Botany, 25, 1-106.

[50] Fayed, A.A. and El Naggar, S.M. (1988) Taxonomic Studies on Cruciferae in Egypt 2. Taxonomic Significance of the Seed Coat Sculpture in Species of Tribe Brassiceae. Taeckholmia, 11, 87-95.

[51] Fayed, A.A. and El Naggar, S.M. (1996) Taxonomic Studies on Cruciferae in Egypt 4. Seed Morphology and Taxonomy of the Egyptian Species of Lepidieae. Bulletin of the Faculty of Science. Assiut University, 25, 43-50.

[52] Koul, K., Ranjna, N. and Raina, S.N. (2000) Seed Coat Microsculpturing in Brassica and Allied Genera Subtribes Brassicinae, Raphaninae, Moricandiinae). Annals of Botany, 86, 85-97. https://doi.org/10.1006/anbo.2000.1197

[53] Abdel Khalik, K. and Maesn, V. (2002) Seed Morphology of Some Tribes of Brassicaceae Implication for Taxonomy and Species Identification for the Flora of Egypt. Blumea, 47, 363-383.

[54] Tantawy, M.E., Khalifa, S.F., Hassan, S.A. and Al-Rabıai, G.T. (2004) Seed Exomorphic Characters of Some Brassicaceae (LM and SEM Study). International Journal of Agriculture \& Biology, 6, 821-830.

[55] El Naggar, S.M. (2005) Seed Coat Micro-Sculpturing and the Systematic of the Egyptian Brassicaceae (Magnoliopsida). Flora Mediteranea, 15, 581-598.

[56] Kasem, W.T., Ghareeb, A. and Marwa, E. (2011). Seed Morphology and Seed Coat Sculpturing of 32 Taxa of Family Brassicaceae. Journal of American Studies, 2, 166-178.

[57] EL-Habashy, I.E., Abdel-Hameed1, U.K., Abu Ziada, M.E.A. and Abd El-Moteleb, M. (2013) Inter-Specific Relationships among Some Taxa of Brassicaceae (L) Based on Macromorphology, Lamina Architecture, Stomatography and Palynological Criteria. Vegetos-An International Journal of Plant Research, 26, 1-14. https://doi.org/10.5958/j.2229-4473.26.2.047

[58] Bona, M., (2013) Seed-Coat Microsculpturing of Turkish Lepidium (Brassicaceae) and Its Systematic Application. Turkish Journal of Botany, 37, 662-668.

[59] Özüdoğru, B., Akaydinb, G., Erika, S. and Mummenhoff, K. (2016) Seed Morphology of Ricotia (Brassicaceae) and Its Phylogenetic and Systematic Implication. Flora 
-Morphology, Distribution, Functional Ecology of Plants, 222, 60-67. https://doi.org/10.1016/j.flora.2016.03.013

[60] Hani, M., Lebazda, R. and Fenni1, M. (2017) Studies of Morphological Characteristics and Production of Seeds Weeds of Species of Family Brassicaceae (Cruciferous) in Setifian High Plateau, Algeria. Annual Research \& Review in Biology, 12, 1-9. https://doi.org/10.9734/ARRB/2017/33473

[61] Barthlott, W. (1990) Scanning Electron Microscopy of the Epidermal Surface in Plants. In: Claugher, D., Ed., Scanning Electron Microscopy in Taxonomy and Functional Morphology, Clarendon Press, Oxford, 69-94.

[62] Stearn, W.T. (1992) Botanical Latin. David \& Charles Pub, London.

[63] Bailey, C.D., Koch, M.A., Mayer, M., Mummenhoff, K., O’Kane, S.L., Warwick, S.I., Windham, M.D. and Al-Shehbaz, I.A. (2006) Toward a Global Phylogeny of the Brassicaceae. Molecular Biology and Evolution, 23, 2142-2160.

https://doi.org/10.1093/molbev/msl087

[64] Dudley, T.R. and Cullen, J. (1965) Studies in the Old World Alysseae Hayek. Feddes Repertorium, 71, 218-228. https://doi.org/10.1002/fedr.19650710105

[65] Warwick, S.I., Sauder, C.A. and Al-Shehbaz, I.A. (2008) Phylogenetic Relationships in the Tribe Alysseae (Brassicaceae) Based on Nuclear Ribosomal ITS DNA Sequences. Botany-Botanique, 86, 315-336. https://doi.org/10.1139/B08-013

[66] German, D.A. (2009) A Check-List and the System of the Cruciferae of Altai. Komarovia, 6, 80-88.

[67] Koch, M.A., Dobes, C., Schmickl, R., Klimes, L. and Lysak, M.A. (2007) Supernetwork Identifies Multiple Events of Plastid trnF(GAA) Pseudogene Evolution in the Brassicaceae. Molecular Biology and Evolution, 24, 63-73. https://doi.org/10.1093/molbev/msl130

[68] Khosravi, A.R., Mohsenzadeh, S. and Mummenhoff, K. (2009) Phylogenetic Relationships of Old World Brassicaceae from Iran Based on Nuclear Ribosomal DNA Sequences. Biochemical Systematics and Ecology, 37, 106-115. https://doi.org/10.1016/j.bse.2009.01.010

[69] Beilstein, M.A., Al-Shehbaz, I.A., Mathews, S. and Kellogg, E.A. (2008) Brassicaceae Phylogeny Inferred from Phytochrome $\mathrm{A}$ and $n d h \mathrm{~F}$ Sequence Data: Tribes and Trichomes Revisited. American Journal of Botany, 95, 1307-1327. https://doi.org/10.3732/ajb.0800065

[70] Mitchell, A.D. and Heenan, P.B. (2000) Systematic Relationships of New Zealand Endemic Brassicaceae Inferred from nrDNA ITS Sequence Data. Systematic Botany, 25, 98-105. https://doi.org/10.2307/2666676

[71] Galloway, G.L., Malmberg, R.L. and Price, R.A. (1998) Phylogenetic Utility of the Nuclear Gene Arginine Decarboxylase: An Example from Brassicaceae. Molecular Biology and Evolution, 15, 1312-1320. https://doi.org/10.1093/oxfordjournals.molbev.a025859

[72] Koch, M. and Hurka, H. (1999) Isozyme Analysis in the Polyploid Complex Microthlaspi perfoliatum (L.) F. K. Meyer: Morphology, Biogeography and Evolutionary History. Flora, 194, 33-48. https://doi.org/10.1016/S0367-2530(17)30877-0

[73] Koch, M.A., Haubold, B. and Mitchell-Olds, T. (2001) Molecular Systematics of the Brassicaceae: Evidence from Coding Plastidic matK and Nuclear Chs Sequences. American Journal of Botany, 88, 534-544. https://doi.org/10.2307/2657117

[74] Al-Shehbaz, I.A. (1988) The Genera of Sisymbrieae (Cruciferae; Brassicaceae), the Southeastern United States. Journal of the Arnold Arboretum, 69, 213-237. https://doi.org/10.5962/bhl.part.2393 
[75] Warwick, S.I., Al-Shehbaz, I.A., Price, R.A. and Sauder, C. (2002) Phylogeny of Sisymbrium (Brassicaceae) Based on ITS Sequences of Nuclear Ribosomal DNA. Canadian Journal of Botany, 80, 1002-1017. https://doi.org/10.1139/b02-089

[76] Warwick, S.I., Al-Shehbaz, I.A., Sauder, C., Harris, J.G. and Koch, M. (2004) Phylogeny of Braya and Neotorularia (Brassicaceae) Based on Nuclear Ribosomal Internal Transcribed Spacer and Chloroplast trnL Intron Sequences. Canadian Journal of Botany, 82, 376-392. https://doi.org/10.1139/b04-012

[77] Warwick, S.I., Al-Shehbaz, I.A., Sauder, C., Murray, D.F. and Mummenhoff, K. (2004) Phylogeny of Smelowskia and Related Genera (Brassicaceae) Based on Nuclear ITS DNA and Chloroplast trnL Intron Sequences. Annals of the Missouri Botanical Garden, 91, 99-123.

[78] Zunk, K., Mummenhoff, K. and Hurka, H. (1993) Chloroplast Restriction Site Variation in the Brassicaceae, Tribe Lepidieae. Plant Molecular Evolution Newsl, 3 , 40-44.

[79] Price, R.A., Palmer, J.D. and Al-Shehbaz, I.A. (1994) Systematic Relationships of Arabidopsis: A Molecular and Morphological Approach. In: Meyerowitz, E. and Somerville, C., Eds., Arabidopsis, Cold Spring Harbor Press, Cold Spring Harbor, NY, 719.

[80] Les, D.H. (1994) Molecular Systematic and Taxonomy of Lake Cress (Neobeckia aquatica; Brassicaceae), an Imperilled Aquatic Mustard. Aquatic Botany, 49, 149-165. https://doi.org/10.1016/0304-3770(94)90035-3

[81] Franzke, A., Pollman, K., Bleeker, W., Kohrt, R. and Hurka, H. (1998) Molecular Systematics of Cardamine and Allied Genera (Brassicaceae): ITS and Non-Coding Chloroplast DNA. Folia Geobotanica, 33, 225-240.

https://doi.org/10.1007/BF03216204

[82] Sweeney, P.W. and Price, R.A. (2000) Polyphyly of the Genus Dentaria L. (Brassicaceae): Evidence from trnL Intron and $n d h F$ Sequence Data. Systematic Botany, 25, 468-478. https://doi.org/10.2307/2666690

[83] Bleeker, W., Franzke, A., Pollmann, K., Brown, A.H.D. and Hurka, H. (2002a) Phylogeny and Biogeography of Southern Hemisphere High-Mountain Cardamine Species (Brassicaceae). Australian Systematic Botany, 15, 575-581. https://doi.org/10.1071/SB01026

[84] Bleeker, W., Weber-Sparenberg, C. and Hurka, H. (2002b) Chloroplast DNA Variation and Biogeography in the Genus Rorippa Scop. (Brassicaceae). Plant Biology, 4, 104-111. https://doi.org/10.1055/s-2002-20442

[85] Warwick, S.I. and Black L.D. (1997) Molecular Phylogenies from Theory to Application in Brassica and Allies (Tribe Brassiceae, Brassicaceae). Opera Botanica, 132, 159-168

[86] Warwick, S.I. and Black, L.D. (1997b) Phylogenetic Implications of Chloroplast DNA Restriction Site Variation in Subtribes Raphaninae and Cakilinae (Brassicaceae, Tribe Brassiceae). Canadian Journal of Botany, 75, 960-973. https://doi.org/10.1139/b97-107

[87] Lysak, M.A., Koch, M.A., Pecinka, A. and Schubert, I. (2005) Chromosome Triplication Found across the Tribe. Genome Research, 15, 516-525.

https://doi.org/10.1101/gr.3531105

[88] Mandáková, T. and Lysak, M.A. (2008) Chromosomal Phylogeny and Karyotype Evolution in $\mathrm{x}=7$ Crucifer Species (Brassicaceae). Plant Cell, 20, 2559-2570.

https://doi.org/10.1105/tpc.108.062166 